\title{
Phosphatidylinositol kinases (version 2020.2) in the IUPHAR/BPS Guide to Pharmacology Database
}

\author{
Mohib Uddin ${ }^{1}$ \\ 1. AstraZeneca, Sweden
}

\begin{abstract}
Phosphatidylinositol may be phosphorylated at either 3- or 4- positions on the inositol ring by PI 3-kinases or PI 4-kinases, respectively.

Phosphatidylinositol 3-kinases

Phosphatidylinositol 3-kinases (PI3K, provisional nomenclature) catalyse the introduction of a phosphate into the 3-position of phosphatidylinositol (PI), phosphatidylinositol 4-phosphate (PIP) or phosphatidylinositol 4,5bisphosphate $\left(\mathrm{PIP}_{2}\right)$. There is evidence that PI3K can also phosphorylate serine/threonine residues on proteins. In addition to the classes described below, further serine/threonine protein kinases, including ATM (Q13315) and mTOR (P42345), have been described to phosphorylate phosphatidylinositol and have been termed PI3Krelated kinases. Structurally, PI3Ks have common motifs of at least one C2, calcium-binding domain and helical domains, alongside structurally-conserved catalytic domains. wortmannin and LY 294002 are widely-used inhibitors of PI3K activities. wortmannin is irreversible and shows modest selectivity between Class I and Class II PI3K, while LY294002 is reversible and selective for Class I compared to Class II PI3K.
\end{abstract}

Class I PI3Ks (EC 2.7.1.153) phosphorylate phosphatidylinositol 4,5-bisphosphate to generate phosphatidylinositol 3,4,5-trisphosphate and are heterodimeric, matching catalytic and regulatory subunits. Class IA PI3Ks include $\mathrm{p} 110 \alpha, \mathrm{p} 110 \beta$ and $\mathrm{p} 110 \delta$ catalytic subunits, with predominantly p85 and p55 regulatory subunits. The single catalytic subunit that forms Class IB PI3K is p110y. Class IA PI3Ks are more associated with receptor tyrosine kinase pathways, while the Class IB PI3K is linked more with GPCR signalling.

Class II PI3Ks (EC 2.7.1.154) phosphorylate phosphatidylinositol to generate phosphatidylinositol 3-phosphate (and possibly phosphatidylinositol 4-phosphate to generate phosphatidylinositol 3,4-bisphosphate). Three monomeric members exist, PI3K-C2 $\alpha, \beta$ and $\beta$, and include Ras-binding, Phox homology and two C2domains.

The only class III PI3K isoform (EC 2.7.1.137) is a heterodimer formed of a catalytic subunit (VPS34) and regulatory subunit (VPS15).

Phosphatidylinositol 4-kinases

Phosphatidylinositol 4-kinases (EC 2.7.1.67) generate phosphatidylinositol 4-phosphate and may be divided into higher molecular weight type III and lower molecular weight type II forms.

\section{Contents}

This is a citation summary for Phosphatidylinositol kinases in the Guide to Pharmacology database (GtoPdb). It exists purely as an adjunct to the database to facilitate the recognition of citations to and from the database by citation analyzers. Readers will almost certainly want to visit the relevant sections of the database which are given here under database links.

GtoPdb is an expert-driven guide to pharmacological targets and the substances that act on them. GtoPdb is a reference work which is most usefully represented as an on-line database. As in any publication this work should be appropriately cited, and the papers it cites should also be recognized. This document provides a citation for the relevant parts of the database, and also provides a reference list for the research cited by those parts. 
Please note that the database version for the citations given in GtoPdb are to the most recent preceding version in which the family or its subfamilies and targets were substantially changed. The links below are to the current version. If you need to consult the cited version, rather than the most recent version, please contact the GtoPdb curators.

\section{Database links}

Phosphatidylinositol kinases

http://www.guidetopharmacology.org/GRAC/FamilyDisplayForward?familyld=781

Enzymes

PI4KIIIa/PIK4CA(phosphatidylinositol 4-kinase alpha)

http://www. guidetopharmacology.org/GRAC/ObjectDisplayForward?objectld=2148

PI3Ka(phosphatidylinositol-4,5-bisphosphate 3-kinase catalytic subunit alpha)

http://www. guidetopharmacology.org/GRAC/ObjectDisplayForward?objectld=2153

PI4KIIIß/PIK4CB(phosphatidylinositol 4-kinase beta)

http://www. guidetopharmacology.org/GRAC/ObjectDisplayForward?objectld=2149

PI3K $\beta$ (phosphatidylinositol-4,5-bisphosphate 3-kinase catalytic subunit beta)

http://www. guidetopharmacology.org/GRAC/ObjectDisplayForward?objectld=2154

PI4KIIa/PI4K2A(phosphatidylinositol 4-kinase type 2 alpha)

http://www. guidetopharmacology.org/GRAC/ObjectDisplayForward?objectld=2498

PI3Ky(phosphatidylinositol-4,5-bisphosphate 3-kinase catalytic subunit gamma)

http://www.guidetopharmacology.org/GRAC/ObjectDisplayForward?objectld=2156

PI4KII/PI4K2B(phosphatidylinositol 4-kinase type 2 beta)

http://www. guidetopharmacology.org/GRAC/ObjectDisplayForward?objectld=2499

PI3K $\delta$ (phosphatidylinositol-4,5-bisphosphate 3-kinase catalytic subunit delta)

http://www. guidetopharmacology.org/GRAC/ObjectDisplayForward?objectld=2155

p85a/PIK3R1(phosphoinositide-3-kinase regulatory subunit 1)

http://www. guidetopharmacology.org/GRAC/ObjectDisplayForward?objectld=2503

p85ß/PIK3R2 (phosphoinositide-3-kinase regulatory subunit 2)

http://www. guidetopharmacology.org/GRAC/ObjectDisplayForward?objectld=2504

p55y/PIK3R3(phosphoinositide-3-kinase regulatory subunit 3)

http://www. guidetopharmacology.org/GRAC/ObjectDisplayForward?objectld=2505

p150/VPS15/PIK3R4(phosphoinositide-3-kinase regulatory subunit 4)

http://www. guidetopharmacology.org/GRAC/ObjectDisplayForward?objectld=2157

p101/PIK3R5 (phosphoinositide-3-kinase regulatory subunit 5)

http://www. guidetopharmacology.org/GRAC/ObjectDisplayForward?objectld=2506

p87/PIK3R6(phosphoinositide-3-kinase regulatory subunit 6)

http://www. guidetopharmacology.org/GRAC/ObjectDisplayForward?objectld=2507

C2a/PIK3C2A(phosphatidylinositol-4-phosphate 3-kinase catalytic subunit type 2 alpha)

http://www. guidetopharmacology.org/GRAC/ObjectDisplayForward?objectld=2150

C2ß/PIK3C2B(phosphatidylinositol-4-phosphate 3-kinase catalytic subunit type 2 beta)

http://www. guidetopharmacology.org/GRAC/ObjectDisplayForward?objectld=2151

C2y/PIK3C2G(phosphatidylinositol-4-phosphate 3-kinase catalytic subunit type 2 gamma)

http://www.guidetopharmacology.org/GRAC/ObjectDisplayForward?objectld=2288

VPS34(phosphatidylinositol 3-kinase catalytic subunit type 3)

http://www. guidetopharmacology.org/GRAC/ObjectDisplayForward?objectld=2152

\section{References}

1. Adams JL, Smothers J, Srinivasan R and Hoos A. (2015) Big opportunities for small molecules in immunooncology. Nat Rev Drug Discov 14: 603-22 [PMID:26228631]

2. Ali AY, Wu X, Eissa N, Hou S, Ghia JE, Murooka TT, Banerji V, Johnston JB, Lin F and Gibson SBet al.. (2018) Distinct roles for phosphoinositide 3-kinases y and $\delta$ in malignant B cell migration. Leukemia 32: 1958-1969 [PMID:29479062]

3. Ali K, Soond DR, Piñeiro R, Hagemann T, Pearce W, Lim EL, Bouabe H, Scudamore CL, Hancox T and Maecker $\mathrm{H}$ et al.. (2014) Inactivation of $\mathrm{PI}(3) \mathrm{K}$ p110 breaks regulatory T-cell-mediated immune tolerance to cancer. Nature 510: 407-11 [PMID:24919154]

4. Allen RA, Brookings DC, Powell MJ, Delgado J, Shuttleworth LK, Merriman M, Fahy IJ, Tewari R, Silva JP and Healy LJ et al.. (2017) Seletalisib: Characterization of a Novel, Potent, and Selective Inhibitor of PI3Kס. J. Pharmacol. Exp. Ther. 361: 429-440 [PMID:28442583]

5. Angulo I, Vadas O, Garçon F, Banham-Hall E, Plagnol V, Leahy TR, Baxendale H, Coulter T, Curtis J and Wu C et al.. (2013) Phosphoinositide 3-kinase $\delta$ gene mutation predisposes to respiratory infection and airway damage. Science 342: 866-71 [PMID:24136356]

6. Apsel B, Blair JA, Gonzalez B, Nazif TM, Feldman ME, Aizenstein B, Hoffman R, Williams RL, Shokat KM 
and Knight ZA. (2008) Targeted polypharmacology: discovery of dual inhibitors of tyrosine and phosphoinositide kinases. Nat. Chem. Biol. 4: 691-9 [PMID:18849971]

7. Backer JM. (2008) The regulation and function of Class III PI3Ks: novel roles for Vps34.Biochem. J. 410: 1-17 [PMID:18215151]

8. Balla A, Kim YJ, Varnai P, Szentpetery Z, Knight Z, Shokat KM and Balla T. (2008) Maintenance of hormone-sensitive phosphoinositide pools in the plasma membrane requires phosphatidylinositol 4-kinase IIlalpha. Mol. Biol. Cell 19: 711-21 [PMID:18077555]

9. Balla A, Tuymetova G, Barshishat M, Geiszt M and Balla T. (2002) Characterization of type II phosphatidylinositol 4-kinase isoforms reveals association of the enzymes with endosomal vesicular compartments. J. Biol. Chem. 277: 20041-50 [PMID:11923287]

10. Barda DA and Mader MM.. (2013) PI3 kinase/mTOR dual inhibitor. Patent number: US8440829 B2.

11. Barlaam B, Cosulich S, Delouvrié B, Ellston R, Fitzek M, Germain H, Green S, Hancox U, Harris CS and Hudson K et al.. (2015) Discovery of 1-(4-(5-(5-amino-6-(5-tert-butyl-1,3,4-oxadiazol-2-yl)pyrazin-2-yl)-1ethyl-1,2,4-triazol-3-yl)piperidin-1-yl)-3-hydroxypropan-1-one (AZD8835): A potent and selective inhibitor of PI3Ka and PI3K $\delta$ for the treatment of cancers. Bioorg. Med. Chem. Lett. 25: 5155-62 [PMID:26475521]

12. Bergamini G, Bell K, Shimamura S, Werner T, Cansfield A, Müller K, Perrin J, Rau C, Ellard K and Hopf C et al.. (2012) A selective inhibitor reveals PI3Ky dependence of $\mathrm{T}(\mathrm{H}) 17$ cell differentiation.Nat. Chem. Biol. 8: 576-82 [PMID:22544264]

13. Berndt A, Miller S, Williams O, Le DD, Houseman BT, Pacold JI, Gorrec F, Hon WC, Liu Y and Rommel C et al.. (2010) The p110 delta structure: mechanisms for selectivity and potency of new PI(3)K inhibitors. Nat. Chem. Biol. 6: 117-24 [PMID:20081827]

14. Bonazzi S, Goold CP, Gray A, Thomsen NM, Nunez J, Karki RG, Gorde A, Biag JD, Malik HA and Sun Y et al.. (2020) Discovery of a Brain-Penetrant ATP-Competitive Inhibitor of the Mechanistic Target of Rapamycin (mTOR) for CNS Disorders. J. Med. Chem. 63: 1068-1083 [PMID:31955578]

15. Borsari C, Rageot D, Dall'Asen A, Bohnacker T, Melone A, Sele AM, Jackson E, Langlois JB, Beaufils F and Hebeisen P et al.. (2019) A Conformational Restriction Strategy for the Identification of a Highly Selective Pyrimido-pyrrolo-oxazine mTOR Inhibitor. J. Med. Chem. 62: 8609-8630 [PMID:31465220]

16. Braun M-G, Hanan E, Staben ST, Heald RA, Macleod C and Elliott R. (2017) Benzoxazepin oxazolidinone compounds and methods of use Patent number: US20170015678.

17. Brown SD and Matthews DJ. (2012) (alpha- substituted aralkylamino and heteroarylalkylamino) pyrimidinyl and 1,3,5 -triazinyl benzimidazoles, pharmaceutical compositions containing them, and these compounds for use in treating proliferative diseases Patent number: WO2012135160A1.

18. Burger MT, Pecchi S, Wagman A, Ni ZJ, Knapp M, Hendrickson T, Atallah G, Pfister K, Zhang Y and Bartulis S et al.. (2011) Identification of NVP-BKM120 as a Potent, Selective, Orally Bioavailable Class I PI3 Kinase Inhibitor for Treating Cancer. ACS Med Chem Lett 2: 774-9 [PMID:24900266]

19. Camps M, Rückle T, Ji H, Ardissone V, Rintelen F, Shaw J, Ferrandi C, Chabert C, Gillieron C and Françon B et al.. (2005) Blockade of PI3Kgamma suppresses joint inflammation and damage in mouse models of rheumatoid arthritis. Nat. Med. 11: 936-43 [PMID:16127437]

20. Canaud G. (2017) BYL719 (ALPELISIB) FOR USE IN THE TREATMENT OF PIK3CA-RELATED OVERGROWTH SPECTRUM (PROS - CLOVES SYNDROME) Patent number: WO2017140828.

21. Cano C, Saravanan K, Bailey C, Bardos J, Curtin NJ, Frigerio M, Golding BT, Hardcastle IR, Hummersone MG and Menear KA et al.. (2013) 1-substituted (Dibenzo[b,d]thiophen-4-yl)-2-morpholino-4H-chromen-4ones endowed with dual DNA-PK/PI3-K inhibitory activity. J. Med. Chem. 56: 6386-401 [PMID:23855836]

22. Castro-Falcón G, Seiler GS, Demir Ö, Rathinaswamy MK, Hamelin D, Hoffmann RM, Makowski SL, Letzel AC, Field SJ and Burke JE et al.. (2018) Neolymphostin A Is a Covalent Phosphoinositide 3-Kinase (PI3K)/Mammalian Target of Rapamycin (mTOR) Dual Inhibitor That Employs an Unusual Electrophilic Vinylogous Ester. J. Med. Chem. 61: 10463-10472 [PMID:30380865]

23. Certal V, Carry JC, Halley F, Virone-Oddos A, Thompson F, Filoche-Rommé B, El-Ahmad Y, Karlsson A, Charrier $V$ and Delorme $C$ et al.. (2014) Discovery and optimization of pyrimidone indoline amide PI3K $\beta$ inhibitors for the treatment of phosphatase and tensin homologue (PTEN)-deficient cancers. J. Med. Chem. 57: 903-20 [PMID:24387221]

24. Certal V, Halley F, Virone-Oddos A, Delorme C, Karlsson A, Rak A, Thompson F, Filoche-Rommé B, ElAhmad $Y$ and Carry JC et al.. (2012) Discovery and optimization of new benzimidazole- and benzoxazolepyrimidone selective PI3K $\beta$ inhibitors for the treatment of phosphatase and TENsin homologue (PTEN)deficient cancers. J. Med. Chem. 55: 4788-805 [PMID:22524426]

25. Cheng H, Li C, Bailey S, Baxi SM, Goulet L, Guo L, Hoffman J, Jiang Y, Johnson TO and Johnson TV $\notin t$ al.. (2013) Discovery of the Highly Potent PI3K/mTOR Dual Inhibitor PF-04979064 through StructureBased Drug Design. ACS Med Chem Lett 4: 91-7 [PMID:24900568]

26. Cherian PT, Koikov LN, Wortman MD and Knittel JJ. (2009) Exploring the PI3K alpha and gamma binding sites with 2,6-disubstituted isonicotinic derivatives. Bioorg. Med. Chem. Lett. 19: 2215-9 [PMID:19297156]

27. Collier PN, Martinez-Botella G, Cornebise M, Cottrell KM, Doran JD, Griffith JP, Mahajan S, Maltais F, Moody CS and Huck EP et al.. (2015) Structural basis for isoform selectivity in a class of benzothiazole inhibitors of phosphoinositide 3-kinase y. J. Med. Chem. 58: 517-21 [PMID:24754609]

28. Cooke NG, Fernandes GDSP, Graveleau N, Hebach C, Hogenauer K, Hollingworth G, Smith AB, 
Soldermann N, Stowasser F and Strang R et al.. (2012) Tetrahydro-pyrido-pyrimidine derivatives Patent number: WO2012004299.

29. Crank MC, Grossman JK, Moir S, Pittaluga S, Buckner CM, Kardava L, Agharahimi A, Meuwissen H, Stoddard J and Niemela J et al.. (2014) Mutations in PIK3CD can cause hyper IgM syndrome (HIGM) associated with increased cancer susceptibility. J. Clin. Immunol. 34: 272-6 [PMID:24610295]

30. Cushing TD, Hao X, Shin Y, Andrews K, Brown M, Cardozo M, Chen Y, Duquette J, Fisher B and Gonzalez-Lopez de Turiso F et al.. (2015) Discovery and in vivo evaluation of (S)-N-(1-(7-fluoro-2-(pyridin2-yl)quinolin-3-yl)ethyl)-9H-purin-6-amine (AMG319) and related PI3K $\delta$ inhibitors for inflammation and autoimmune disease. J. Med. Chem. 58: 480-511 [PMID:25469863]

31. D'Angelo ND, Kim TS, Andrews K, Booker SK, Caenepeel S, Chen K, D'Amico D, Freeman D, Jiang J and Liu L et al.. (2011) Discovery and optimization of a series of benzothiazole phosphoinositide 3-kinase (PI3K)/mammalian target of rapamycin (mTOR) dual inhibitors. J. Med. Chem. 54: 1789-811 [PMID:21332118]

32. Davis MI, Hunt JP, Herrgard S, Ciceri P, Wodicka LM, Pallares G, Hocker M, Treiber DK and Zarrinkar PP. (2011) Comprehensive analysis of kinase inhibitor selectivity. Nat. Biotechnol. 29: 1046-51 [PMID:22037378]

33. de la Morena M, Haire RN, Ohta Y, Nelson RP, Litman RT, Day NK, Good RA and Litman GW. (1995) Predominance of sterile immunoglobulin transcripts in a female phenotypically resembling Bruton's agammaglobulinemia. Eur. J. Immunol. 25: 809-15 [PMID:7705412]

34. Deau MC, Heurtier L, Frange P, Suarez F, Bole-Feysot C, Nitschke P, Cavazzana M, Picard C, Durandy A and Fischer A et al.. (2014) A human immunodeficiency caused by mutations in the PIK3R1 gene.J. Clin. Invest. 124: 3923-8 [PMID:25133428]

35. Dittmann A, Werner T, Chung CW, Savitski MM, Fälth Savitski M, Grandi P, Hopf C, Lindon M, Neubauer $G$ and Prinjha RK et al.. (2014) The commonly used PI3-kinase probe LY294002 is an inhibitor of BET bromodomains. ACS Chem. Biol. 9: 495-502 [PMID:24533473]

36. Dowdle WE, Nyfeler B, Nagel J, Elling RA, Liu S, Triantafellow E, Menon S, Wang Z, Honda A and Pardee $\mathrm{G}$ et al.. (2014) Selective VPS34 inhibitor blocks autophagy and uncovers a role for NCOA4 in ferritin degradation and iron homeostasis in vivo. Nat. Cell Biol. 16: 1069-79 [PMID:25327288]

37. Down K, Amour A, Baldwin IR, Cooper AW, Deakin AM, Felton LM, Guntrip SB, Hardy C, Harrison ZA and Jones KL et al.. (2015) Optimization of Novel Indazoles as Highly Potent and Selective Inhibitors of Phosphoinositide 3-Kinase $\delta$ for the Treatment of Respiratory Disease. J. Med. Chem. 58: 7381-99 [PMID:26301626]

38. Dulau Florea AE, Braylan RC, Schafernak KT, Williams KW, Daub J, Goyal RK, Puck JM, Rao VK, Pittaluga S and Holland SM et al.. (2017) Abnormal B-cell maturation in the bone marrow of patients with germline mutations in PIK3CD. J. Allergy Clin. Immunol. 139: 1032-1035.e6 [PMID:27697496]

39. Evans CA, Liu T, Lescarbeau A, Nair SJ, Grenier L, Pradeilles JA, Glenadel Q, Tibbitts T, Rowley AM and DiNitto JP et al.. (2016) Discovery of a Selective Phosphoinositide-3-Kinase (PI3K)-y Inhibitor (IPI-549) as an Immuno-Oncology Clinical Candidate. ACS Med Chem Lett 7: 862-7 [PMID:27660692]

40. Fokas E, Prevo R, Pollard JR, Reaper PM, Charlton PA, Cornelissen B, Vallis KA, Hammond EM, Olcina MM and Gillies McKenna W et al.. (2012) Targeting ATR in vivo using the novel inhibitor VE-822 results in selective sensitization of pancreatic tumors to radiation. Cell Death Dis 3: e441 [PMID:23222511]

41. Folkes AJ, Ahmadi K, Alderton WK, Alix S, Baker SJ, Box G, Chuckowree IS, Clarke PA, Depledge P and Eccles SA et al.. (2008) The identification of 2-(1H-indazol-4-yl)-6-(4-methanesulfonyl-piperazin-1ylmethyl)-4-morpholin-4-yl-thieno[3,2-d]pyrimidine (GDC-0941) as a potent, selective, orally bioavailable inhibitor of class I PI3 kinase for the treatment of cancer . J. Med. Chem. 51: 5522-32 [PMID:18754654]

42. Fraser C, Carragher NO and Unciti-Broceta A. (2016) eCF309: a potent, selective and cell-permeable mTOR inhibitor Medchemcomm 7: 471-477

43. Furet P, Guagnano V, Fairhurst RA, Imbach-Weese P, Bruce I, Knapp M, Fritsch C, Blasco F, Blanz J and Aichholz R et al.. (2013) Discovery of NVP-BYL719 a potent and selective phosphatidylinositol-3 kinase alpha inhibitor selected for clinical evaluation. Bioorg. Med. Chem. Lett. 23: 3741-8 [PMID:23726034]

44. Gangadhara G, Dahl G, Bohnacker T, Rae R, Gunnarsson J, Blaho S, Öster L, Lindmark H, Karabelas K and Pemberton N et al.. (2019) A class of highly selective inhibitors bind to an active state of PI3KyNat. Chem. Biol. 15: 348-357 [PMID:30718815]

45. Gehrmann T, Gülkan H, Suer S, Herberg FW, Balla A, Vereb G, Mayr GW and Heilmeyer Jr LM. (1999) Functional expression and characterisation of a new human phosphatidylinositol 4-kinase PI4K230. Biochim. Biophys. Acta 1437: 341-56 [PMID:10101268]

46. Goldberg FW, Finlay MRV, Ting AKT, Beattie D, Lamont GM, Fallan C, Wrigley GL, Schimpl M, Howard MR and Williamson B et al.. (2020) The Discovery of 7-Methyl-2-[(7-methyl[1,2,4]triazolo[1,5a]pyridin-6yl)amino]-9-(tetrahydro-2H-pyran-4-yl)-7,9-dihydro-8H-purin-8-one (AZD7648), a Potent and Selective DNA-Dependent Protein Kinase (DNA-PK) Inhibitor. J. Med. Chem. [PMID:31851518]

47. Gopalsamy A, Bennett EM, Shi M, Zhang WG, Bard J and Yu K. (2012) Identification of pyrimidine derivatives as hSMG-1 inhibitors. Bioorg. Med. Chem. Lett. 22: 6636-41 [PMID:23021994]

48. Griffin RJ, Fontana G, Golding BT, Guiard S, Hardcastle IR, Leahy JJ, Martin N, Richardson C, Rigoreau L and Stockley M et al.. (2005) Selective benzopyranone and pyrimido[2,1-a]isoquinolin-4-one inhibitors of 
DNA-dependent protein kinase: synthesis, structure-activity studies, and radiosensitization of a human tumor cell line in vitro. J. Med. Chem. 48: 569-85 [PMID:15658870]

49. Hancox U, Cosulich S, Hanson L, Trigwell C, Lenaghan C, Ellston R, Dry H, Crafter C, Barlaam B and Fitzek M et al.. (2015) Inhibition of PI3K $\beta$ signaling with AZD8186 inhibits growth of PTEN-deficient breast and prostate tumors alone and in combination with docetaxel. Mol. Cancer Ther. 14: 48-58 [PMID:25398829]

50. Harris SJ, Foster JG and Ward SG. (2009) PI3K isoforms as drug targets in inflammatory diseases: lessons from pharmacological and genetic strategies. Curr Opin Investig Drugs 10: 1151-62 [PMID:19876783]

51. Hart S, Novotny-Diermayr V, Goh KC, Williams M, Tan YC, Ong LC, Cheong A, Ng BK, Amalini C and Madan B et al.. (2013) VS-5584, a novel and highly selective PI3K/mTOR kinase inhibitor for the treatment of cancer. Mol. Cancer Ther. 12: 151-61 [PMID:23270925]

52. Hausser A, Storz P, Märtens S, Link G, Toker A and Pfizenmaier K. (2005) Protein kinase D regulates vesicular transport by phosphorylating and activating phosphatidylinositol-4 kinase Illbeta at the Golgi complex. Nat. Cell Biol. 7: 880-6 [PMID:16100512]

53. Hayakawa M, Kawaguchi K, Kaizawa H, Koizumi T, Ohishi T, Yamano M, Okada M, Ohta M, Tsukamoto S and Raynaud Fl et al.. (2007) Synthesis and biological evaluation of sulfonylhydrazone-substituted imidazo[1,2-a]pyridines as novel PI3 kinase p110alpha inhibitors. Bioorg. Med. Chem. 15: 5837-44 [PMID:17601739]

54. Heffron TP, Ndubaku CO, Salphati L, Alicke B, Cheong J, Drobnick J, Edgar K, Gould SE, Lee LB and Lesnick JD et al.. (2016) Discovery of Clinical Development Candidate GDC-0084, a Brain Penetrant Inhibitor of PI3K and mTOR. ACS Med Chem Lett 7: 351-6 [PMID:27096040]

55. Henley ZA, Amour A, Barton N, Bantscheff M, Bergamini G, Bertrand SM, Convery M, Down K, Dümpelfeld B and Edwards CD et al.. (2020) Optimization of Orally Bioavailable PI3K $\delta$ Inhibitors and Identification of Vps34 as a Key Selectivity Target. J. Med. Chem. 63: 638-655 [PMID:31855425]

56. Hsieh AC, Liu Y, Edlind MP, Ingolia NT, Janes MR, Sher A, Shi EY, Stumpf CR, Christensen C and Bonham MJ et al.. (2012) The translational landscape of mTOR signalling steers cancer initiation and metastasis. Nature 485: 55-61 [PMID:22367541]

57. Jackson SP, Schoenwaelder SM, Goncalves I, Nesbitt WS, Yap CL, Wright CE, Kenche V, Anderson KE, Dopheide SM and Yuan $Y$ et al.. (2005) PI 3-kinase p110beta: a new target for antithrombotic therapy.Nat. Med. 11: 507-14 [PMID:15834429]

58. Jalota-Badhwar A, Bhatia DR, Boreddy S, Joshi A, Venkatraman M, Desai N, Chaudhari S, Bose J, Kolla LS and Deore V et al.. (2015) P7170: A Novel Molecule with Unique Profile of mTORC1/C2 and Activin Receptor-like Kinase 1 Inhibition Leading to Antitumor and Antiangiogenic Activity. Mol. Cancer Ther. 14: 1095-106 [PMID:25700704]

59. Jović M, Kean MJ, Szentpetery Z, Polevoy G, Gingras AC, Brill JA and Balla T. (2012) Two phosphatidylinositol 4-kinases control lysosomal delivery of the Gaucher disease enzyme, $\beta$ glucocerebrosidase. Mol. Biol. Cell 23: 1533-45 [PMID:22337770]

60. Kim O, Jeong Y, Lee H, Hong SS and Hong S. (2011) Design and synthesis of imidazopyridine analogues as inhibitors of phosphoinositide 3-kinase signaling and angiogenesis. J. Med. Chem. 54: 2455-66 [PMID:21388141]

61. King-Underwood J, Ito K, Murray PJ, Brookfield FA and Brown CJ. (2012) QUINAZOLIN-4 (3H) -ONE DERIVATIVES USED AS PI3 KINASE INHIBITORS Patent number: WO2012052753.

62. Knight SD, Adams ND, Burgess JL, Chaudhari AM, Darcy MG, Donatelli CA, Luengo JI, Newlander KA, Parrish CA and Ridgers LH et al.. (2010) Discovery of GSK2126458, a Highly Potent Inhibitor of PI3K and the Mammalian Target of Rapamycin. ACS Med Chem Lett 1: 39-43 [PMID:24900173]

63. Knight ZA, Gonzalez B, Feldman ME, Zunder ER, Goldenberg DD, Williams O, Loewith R, Stokoe D, Balla A and Toth B et al.. (2006) A pharmacological map of the PI3-K family defines a role for p110alpha in insulin signaling. Cell 125: 733-47 [PMID:16647110]

64. Knight ZA and Shokat KM. (2005) Features of selective kinase inhibitors.Chem. Biol. 12: 621-37 [PMID:15975507]

65. Lannutti BJ, Meadows SA, Herman SE, Kashishian A, Steiner B, Johnson AJ, Byrd JC, Tyner JW, Loriaux MM and Deininger M et al.. (2011) CAL-101, a p110delta selective phosphatidylinositol-3-kinase inhibitor for the treatment of B-cell malignancies, inhibits PI3K signaling and cellular viability. Blood 117: 591-4 [PMID:20959606]

66. Li Y-L, Metcalf BW and Combs AP. (2011) Pyrimidinones as PI3K inhibitors Patent number: WO2011008487.

67. Li Y-L, Yao W, Combs AP, Yue EW, Mei S, Zhu W, Glenn J, Maduskuie TP Jr, Sparks RB and Douty B. (2013) Heterocyclylamines as pi3k inhibitors Patent number: WO2013033569A1.

68. Lin S, Jin J, Liu Y, Tian H, Zhang Y, Fu R, Zhang J, Wang M, Du T and Ji Net al.. (2019) Discovery of 4Methylquinazoline Based PI3K Inhibitors for the Potential Treatment of Idiopathic Pulmonary Fibrosis. J. Med. Chem. 62: 8873-8879 [PMID:31335136]

69. Liu F, Wang J, Yang X, Li B, Wu H, Qi S, Chen C, Liu X, Yu K and Wang Wet al.. (2016) Discovery of a Highly Selective STK16 Kinase Inhibitor. ACS Chem. Biol. 11: 1537-43 [PMID:27082499] 
70. Liu KK, Zhu J, Smith GL, Yin MJ, Bailey S, Chen JH, Hu Q, Huang Q, Li C and Li Qłt al.. (2011) Highly Selective and Potent Thiophenes as PI3K Inhibitors with Oral Antitumor Activity. ACS Med Chem Lett 2: 809-13 [PMID:24900269]

71. Liu N, Rowley BR, Bull CO, Schneider C, Haegebarth A, Schatz CA, Fracasso PR, Wilkie DP, Hentemann $\mathrm{M}$ and Wilhelm SM et al.. (2013) BAY 80-6946 is a highly selective intravenous PI3K inhibitor with potent p110 $\alpha$ and p110 $\delta$ activities in tumor cell lines and xenograft models. Mol. Cancer Ther. 12: 2319-30 [PMID:24170767]

72. Liu Q, Shi Q, Marcoux D, Batt DG, Cornelius L, Qin LY, Ruan Z, Neels J, Beaudoin-Bertrand M and Srivastava AS et al.. (2017) Identification of a Potent, Selective, and Efficacious Phosphatidylinositol 3Kinase $\delta(\mathrm{PI}$ KK $\delta)$ Inhibitor for the Treatment of Immunological Disorders. J. Med. Chem. 60: 5193-5208 [PMID:28541707]

73. Liu Q, Wang J, Kang SA, Thoreen CC, Hur W, Ahmed T, Sabatini DM and Gray NS. (2011) Discovery of 9-(6-aminopyridin-3-yl)-1-(3-(trifluoromethyl)phenyl)benzo[h][1,6]naphthyridin-2(1H)-one (Torin2) as a potent, selective, and orally available mammalian target of rapamycin (mTOR) inhibitor for treatment of cancer. J. Med. Chem. 54: 1473-80 [PMID:21322566]

74. Liu Y, Shreder KR, Gai W, Corral S, Ferris DK and Rosenblum JS. (2005) Wortmannin, a widely used phosphoinositide 3-kinase inhibitor, also potently inhibits mammalian polo-like kinase. Chem. Biol. 12: 99107 [PMID:15664519]

75. Lucas CL, Chandra A, Nejentsev S, Condliffe AM and Okkenhaug K. (2016) PI3Kס and primary immunodeficiencies. Nat. Rev. Immunol. 16: 702-714 [PMID:27616589]

76. Lucas CL, Kuehn HS, Zhao F, Niemela JE, Deenick EK, Palendira U, Avery DT, Moens L, Cannons JL and Biancalana $\mathrm{M}$ et al. (2014) Dominant-activating germline mutations in the gene encoding the $\mathrm{PI}(3) \mathrm{K}$ catalytic subunit p110 $\delta$ result in T cell senescence and human immunodeficiency. Nat. Immunol. 15: 88-97 [PMID:24165795]

77. Luo Y, Xia Y, Wang W, Li Z, Jin Y, Gong Y, He T, Li Q, Li C and Yang J. (2018) Identification of a novel de novo gain-of-function mutation of PIK3CD in a patient with activated phosphoinositide 3-kinase $\delta$ syndrome. Clin. Immunol. 197: 60-67 [PMID:30138677]

78. Maira SM, Stauffer F, Brueggen J, Furet $P$, Schnell C, Fritsch C, Brachmann $S$, Chène $P$, De Pover $A$ and Schoemaker K et al.. (2008) Identification and characterization of NVP-BEZ235, a new orally available dual phosphatidylinositol 3-kinase/mammalian target of rapamycin inhibitor with potent in vivo antitumor activity. Mol. Cancer Ther. 7: 1851-63 [PMID:18606717]

79. Markman B, Tabernero J, Krop I, Shapiro GI, Siu L, Chen LC, Mita M, Melendez Cuero M, Stutvoet S and Birle D et al.. (2012) Phase I safety, pharmacokinetic, and pharmacodynamic study of the oral phosphatidylinositol-3-kinase and mTOR inhibitor BGT226 in patients with advanced solid tumors. Ann. Oncol. 23: 2399-408 [PMID:22357447]

80. Methot JL, Zhou H, Kattar SD, McGowan MA, Wilson K, Garcia Y, Deng Y, Altman M, Fradera X and Lesburg C et al.. (2019) Structure Overhaul Affords a Potent Purine PI3Kס Inhibitor with Improved Tolerability. J. Med. Chem. 62: 4370-4382 [PMID:30986068]

81. Meyers R and Cantley LC. (1997) Cloning and characterization of a wortmannin-sensitive human phosphatidylinositol 4-kinase. J. Biol. Chem. 272: 4384-90 [PMID:9020160]

82. Mårdh CK, Root J, Uddin M, Stenvall K, Malmgren A, Karabelas K and Thomas M. (2017) Targets of Neutrophil Influx and Weaponry: Therapeutic Opportunities for Chronic Obstructive Airway Disease. $J$ Immunol Res 2017: 5273201 [PMID:28596972]

83. Nacht M, Qiao L, Sheets MP, St Martin T, Labenski M, Mazdiyasni H, Karp R, Zhu Z, Chaturvedi P and Bhavsar D et al.. (2013) Discovery of a Potent and Isoform-Selective Targeted Covalent Inhibitor of the Lipid Kinase PI3Ka. J. Med. Chem. 56: 712-21 [PMID:23360348]

84. Ndubaku CO, Heffron TP, Staben ST, Baumgardner M, Blaquiere N, Bradley E, Bull R, Do S, Dotson J and Dudley D et al.. (2013) Discovery of 2-\{3-[2-(1-isopropyl-3-methyl-1H-1,2-4-triazol-5-yl)-5,6-

dihydrobenzo[f]imidazo[1,2-d][1,4]oxazepin-9-yl]-1H-pyrazol-1-yl\}-2-methylpropanamide (GDC-0032): a $\beta$ sparing phosphoinositide 3-kinase inhibitor with high unbound exposure and robust in vivo antitumor activity. J. Med. Chem. 56: 4597-610 [PMID:23662903]

85. Nylander S, Kull B, Björkman JA, Ulvinge JC, Oakes N, Emanuelsson BM, Andersson M, Skärby T, Inghardt T and Fjellström O et al.. (2012) Human target validation of phosphoinositide 3-kinase (PI3K) $\beta$ : effects on platelets and insulin sensitivity, using AZD6482 a novel PI3K $\beta$ inhibitor. J. Thromb. Haemost. 10: 2127-36 [PMID:22906130]

86. Ohwada J, Ebiike H, Kawada H, Tsukazaki M, Nakamura M, Miyazaki T, Morikami K, Yoshinari K, Yoshida $\mathrm{M}$ and Kondoh $\mathrm{O}$ et al.. (2011) Discovery and biological activity of a novel class I PI3K inhibitor, CH5132799. Bioorg. Med. Chem. Lett. 21: 1767-72 [PMID:21316229]

87. Palanki MS, Dneprovskaia E, Doukas J, Fine RM, Hood J, Kang X, Lohse D, Martin M, Noronha G and Soll RM et al.. (2007) Discovery of 3,3'-(2,4-diaminopteridine-6,7-diyl)diphenol as an isozyme-selective inhibitor of PI3K for the treatment of ischemia reperfusion injury associated with myocardial infarction. $J$. Med. Chem. 50: 4279-94 [PMID:17685602]

88. Parkinson GN, Vines D, Driscoll PC and Djordjevic S. (2008) Crystal structures of PI3K-C2alpha PX domain indicate conformational change associated with ligand binding. BMC Struct. Biol. 8: 13 
[PMID:18312637]

89. Pemberton N, Mogemark M, Arlbrandt S, Bold P, Cox RJ, Gardelli C, Holden NS, Karabelas K, Karlsson J and Lever S et al.. (2018) Discovery of Highly Isoform Selective Orally Bioavailable Phosphoinositide 3Kinase (PI3K)-y Inhibitors. J. Med. Chem. 61: 5435-5441 [PMID:29852070]

90. Perry MWD, Björhall K, Bonn B, Carlsson J, Chen Y, Eriksson A, Fredlund L, Hao H, Holden NS and Karabelas K et al.. (2017) Design and Synthesis of Soluble and Cell-Permeable PI3K $\delta$ Inhibitors for LongActing Inhaled Administration. J. Med. Chem. 60: 5057-5071 [PMID:28520415]

91. Pomel V, Klicic J, Covini D, Church DD, Shaw JP, Roulin K, Burgat-Charvillon F, Valognes D, Camps M and Chabert C et al.. (2006) Furan-2-ylmethylene thiazolidinediones as novel, potent, and selective inhibitors of phosphoinositide 3-kinase gamma. J. Med. Chem. 49: 3857-71 [PMID:16789742]

92. Qian C, Lai CJ, Bao R, Wang DG, Wang J, Xu GX, Atoyan R, Qu H, Yin L and Samson Met al.. (2012) Cancer network disruption by a single molecule inhibitor targeting both histone deacetylase activity and phosphatidylinositol 3-kinase signaling. Clin. Cancer Res. 18: 4104-13 [PMID:22693356]

93. Rae W, Gao Y, Ward D, Mattocks CJ, Eren E and Williams AP. (2017) A novel germline gain-of-function variant in PIK3CD. Clin. Immunol. 181: 29-31 [PMID:28578023]

94. Rageot D, Bohnacker T, Melone A, Langlois JB, Borsari C, Hillmann P, Sele AM, Beaufils F, Zvelebil M and Hebeisen P et al.. (2018) Discovery and Preclinical Characterization of 5-[4,6-Bis(\{3-oxa-8azabicyclo[3.2.1]octan-8-yl\})-1,3,5-triazin-2-yl]-4-(difluoromethyl)pyridin-2-amine (PQR620), a Highly Potent and Selective mTORC1/2 Inhibitor for Cancer and Neurological Disorders. J. Med. Chem. 61: 10084-10105 [PMID:30359003]

95. Raynaud FI, Eccles SA, Patel S, Alix S, Box G, Chuckowree I, Folkes A, Gowan S, De Haven Brandon A and Di Stefano F et al.. (2009) Biological properties of potent inhibitors of class I phosphatidylinositide 3kinases: from PI-103 through PI-540, PI-620 to the oral agent GDC-0941. Mol. Cancer Ther. 8: 1725-38 [PMID:19584227]

96. Ren P, Liu Y, Li L, Chan K, Wilson TE and Campbell SF.. (2013) Heterocyclic compounds and uses thereof. Patent number: US20130035324 A1.

97. Ronan B, Flamand O, Vescovi L, Dureuil C, Durand L, Fassy F, Bachelot MF, Lamberton A, Mathieu M and Bertrand T et al.. (2014) A highly potent and selective Vps34 inhibitor alters vesicle trafficking and autophagy. Nat. Chem. Biol. 10: 1013-9 [PMID:25326666]

98. Sadhu C, Masinovsky B, Dick K, Sowell CG and Staunton DE. (2003) Essential role of phosphoinositide 3kinase delta in neutrophil directional movement. J. Immunol. 170: 2647-54 [PMID:12594293]

99. Shugg RP, Thomson A, Tanabe N, Kashishian A, Steiner BH, Puri KD, Pereverzev A, Lannutti BJ, Jirik FR and Dixon SJ et al.. (2013) Effects of isoform-selective phosphatidylinositol 3-kinase inhibitors on osteoclasts: actions on cytoskeletal organization, survival, and resorption. J. Biol. Chem. 288: 35346-57 [PMID:24133210]

100. Sutherlin DP, Bao L, Berry M, Castanedo G, Chuckowree I, Dotson J, Folks A, Friedman L, Goldsmith R and Gunzner J et al.. (2011) Discovery of a potent, selective, and orally available class I phosphatidylinositol 3-kinase (PI3K)/mammalian target of rapamycin (mTOR) kinase inhibitor (GDC-0980) for the treatment of cancer. J. Med. Chem. 54: 7579-87 [PMID:21981714]

101. Taddei DMA, Onions ST, Smith AJ, Copmans AH and Broeckx RLM. (2016) Phosphoinositide 3-kinase inhibitors Patent number: US9227977B2.

102. Tai AW, Bojjireddy N and Balla T. (2011) A homogeneous and nonisotopic assay for phosphatidylinositol 4-kinases. Anal. Biochem. 417: 97-102 [PMID:21704602]

103. Takeda AJ, Zhang Y, Dornan GL, Siempelkamp BD, Jenkins ML, Matthews HF, McElwee JJ, Bi W, Seeborg FO and Su HC et al.. (2017) Novel PIK3CD mutations affecting N-terminal residues of p110 cause activated PIउK $\delta$ syndrome (APDS) in humans. J. Allergy Clin. Immunol. 140: 1152-1156.e10 [PMID:28414062]

104. Tang P, Upton JEM, Barton-Forbes MA, Salvadori MI, Clynick MP, Price AK and Goobie SL. (2018) Autosomal Recessive Agammaglobulinemia Due to a Homozygous Mutation in PIK3R1. J. Clin. Immunol. 38: 88-95 [PMID:29178053]

105. Taracido IC, Harrington EM, Honda A and Keaney E. (2014) Bi-heteroaryl compounds as Vps34 inhibitors Patent number: US8685993.

106. Tsujita Y, Mitsui-Sekinaka K, Imai K, Yeh TW, Mitsuiki N, Asano T, Ohnishi H, Kato Z, Sekinaka Y and Zaha K et al.. (2016) Phosphatase and tensin homolog (PTEN) mutation can cause activated phosphatidylinositol 3-kinase $\delta$ syndrome-like immunodeficiency. J. Allergy Clin. Immunol. 138: 16721680.e10 [PMID:27426521]

107. Uddin M, Lau LC, Seumois G, Vijayanand P, Staples KJ, Bagmane D, Cornelius V, Dorinsky P, Davies DE and Djukanović R. (2013) EGF-induced bronchial epithelial cells drive neutrophil chemotactic and antiapoptotic activity in asthma. PLoS ONE 8: e72502 [PMID:24039773]

108. Vakkalanka SKVS, Bhavar PK, Viswanadha S and Babu G. (2017) Dual selective PI3 delta and gamma kinase inhibitors Patent number: US9790224B2.

109. Vakkalanka SKVS, Muthuppalaniappan M and Nagarathnam D.. (2014) Novel selective pi3k delta inhibitors. Patent number: US20140011819 A1.

110. Vanhaesebroeck B, Welham MJ, Kotani K, Stein R, Warne PH, Zvelebil MJ, Higashi K, Volinia S, 
Downward J and Waterfield MD. (1997) P110delta, a novel phosphoinositide 3-kinase in leukocytes. Proc. Natl. Acad. Sci. U.S.A. 94: 4330-5 [PMID:9113989]

111. Venkatesan AM, Dehnhardt CM, Delos Santos E, Chen Z, Dos Santos O, Ayral-Kaloustian S, Khafizova G, Brooijmans N, Mallon R and Hollander I et al.. (2010) Bis(morpholino-1,3,5-triazine) derivatives: potent adenosine 5'-triphosphate competitive phosphatidylinositol-3-kinase/mammalian target of rapamycin inhibitors: discovery of compound 26 (PKI-587), a highly efficacious dual inhibitor. J. Med. Chem. 53: 263645 [PMID:20166697]

112. Venot Q, Blanc T, Rabia SH, Berteloot L, Ladraa S, Duong JP, Blanc E, Johnson SC, Hoguin C and Boccara O et al.. (2018) Targeted therapy in patients with PIK3CA-related overgrowth syndrome.Nature 558: 540-546 [PMID:29899452]

113. Walker EH, Pacold ME, Perisic O, Stephens L, Hawkins PT, Wymann MP and Williams RL. (2000) Structural determinants of phosphoinositide 3-kinase inhibition by wortmannin, LY294002, quercetin, myricetin, and staurosporine. Mol. Cell 6: 909-19 [PMID:11090628]

114. Wentink M, Dalm V, Lankester AC, van Schouwenburg PA, Schölvinck L, Kalina T, Zachova R, Sediva A, Lambeck A and Pico-Knijnenburg I et al.. (2017) Genetic defects in PI3Kס affect B-cell differentiation and maturation leading to hypogammaglobulineamia and recurrent infections. Clin. Immunol. 176: 77-86 [PMID:28104464]

115. Winkler DG, Faia KL, DiNitto JP, Ali JA, White KF, Brophy EE, Pink MM, Proctor JL, Lussier J and Martin CM et al.. (2013) PI3K- $\delta$ and PI3K-y inhibition by IPI-145 abrogates immune responses and suppresses activity in autoimmune and inflammatory disease models. Chem. Biol. 20: 1364-74 [PMID:24211136]

116. Wodicka LM, Ciceri P, Davis MI, Hunt JP, Floyd M, Salerno S, Hua XH, Ford JM, Armstrong RC and Zarrinkar PP et al.. (2010) Activation state-dependent binding of small molecule kinase inhibitors: structural insights from biochemistry. Chem. Biol. 17: 1241-9 [PMID:21095574]

117. Wu P and Hu Y.. (2012) Small molecules targeting phosphoinositide 3-kinases.Medchemcomm 3: 13371355

118. Xie C, He Y, Zhen M, Wang Y, Xu Y and Lou L. (2017) Puquitinib, a novel orally available PI3Kס inhibitor, exhibits potent antitumor efficacy against acute myeloid leukemia. Cancer Sci. 108: 1476-1484 [PMID:28418085]

119. Xu Z and Lou Y. (2017) Fused heterocyclic compound, preparation method therefor, pharmaceutcial composition, and uses thereof Patent number: US20160244432A1.

120. Yaguchi S, Fukui Y, Koshimizu I, Yoshimi H, Matsuno T, Gouda H, Hirono S, Yamazaki K and Yamori T. (2006) Antitumor activity of ZSTK474, a new phosphatidylinositol 3-kinase inhibitor. J. Natl. Cancer Inst. 98: 545-56 [PMID:16622124]

121. Yang J, Shamji A, Matchacheep S and Schreiber SL. (2007) Identification of a small-molecule inhibitor of class la PI3Ks with cell-based screening. Chem. Biol. 14: 371-7 [PMID:17462572]

122. Yu Y, Han Y, Zhang F, Gao Z, Zhu T, Dong S and Ma M. (2020) Design, Synthesis, and Biological Evaluation of Imidazo[1,2-a]pyridine Derivatives as Novel PI3K/mTOR Dual Inhibitors.J. Med. Chem. [PMID:32069401] 